\title{
elyra
}

\section{Dar colo}

\section{Sónia Baptista}

A

Colagem é como o colo

Das palavras

Onde se dá o colo e fica o colo

Dado.

Ou é

A

Cola

Colagénio

No toque de beiços dados

São dados

Lançados

Laçados

Passados

Colar é o contrário de calar.

Adrienne

Djuna

Edna

Jane

( Na primeira prateleira da estante baixa no compartimento de cima uma, no do meio outra, no cimo entre outra deitada, a última, arrumada).

( Só por isso escolhidas. Amadas só por isso, escolhidas. Coladas). 
Colar é o colo das mulheres, todo o colo das mulheres, amplo, ossudo, carnudo, quente. amplo e quente. Todas as mulheres são coladeiras. Mulheres coladeiras, a colar plantas, a colar plantas. Sem plantar amar mas a colar. A colar folhagens do papel. Flores, floras. A cortar as patas das faunas, os cornos, as caudas. A cortar com tesourinhas. Tesourinhas de unhas, de presas, afiadas, prateadas, douradas. A cortar as cabeças das figuras homens, das figurinhas, cabecinhas, tesourinhas. A cortar a cabeça da história feita de homens e de meretrizes, a cortar as raízes. A cortar aos montes as casas ao meios, a decepar torres, rios, países feios. A cortar ao montes para não calar, em vez do grito, para não matar, a cortar aos montes, nos colos montes a crescer, para colar, colar até morrer.

(Um colar é coisa de colar ao pescoço. À volta do pescoço onde se cala e se não cala, há um colar ao pescoço de coisas juntas, coladas. À volta do pescoço, onde se aperta o pescoço, onde se tira o ar, apertam-se colares, a choker is nothing more than a choking device, darling dearest say it twice).

Nos anos passados colavam as mulheres, calavam as mulheres, colavam as mulheres ,não calavam as mulheres. Ontem, colavam as mulheres, colavam as mulheres. Hoje, calam as mulheres, calam as mulheres, não calam as mulheres, não calam as mulheres.

Dão colo as mulheres, não calam as mulheres.

Nas cartas anónimas colavam as mulheres antes de saber gritar. É passivo, é agressivo, é coisa de ovelha tresmalhada, tosquiada, mirrada, mirrada.

Ficou para as mulheres a vingança, dos venenos, da má língua, das cartas anónimas recortadas, cuspidas, coladas.

Recortes em bíblias, sempre, nos jornais, aos domingos, nas revistas, depois da lida da casa. Esfregada, esfregada.

Falar às mulheres, falar com as mulheres e colar para não calar, agora não calar. Dão-me colo os livros, dá-me colo um livro, pesa na mão um colo, é livre, é vivo.

$\mathrm{Eu}$, que cresci com os homens, com mais homens do que queria, mais homens do que quereria. Eu, que só comecei a falar tarde, a dizer tarde e gritar muito menos. Eu, que gritar só há pouco e fraco primeiro, fraco o grito, fraco o grito primeiro. Primeiro na doideira, na doidice de poder, de o poder fazer, i am woman hear me roar, sem medo ter.

Tão mais tarde, tão mais tarde a colar daqui e dali, a colar a pele, a colar dos nervos, tantos nervos do desejo, tanto desejo de coleccionar, colacionar? As vozes delas, delas, Adrienne Djuna, Edna, Jane. São tantas, tantas, que assombro, tantas, que pasmo, tantas, mas estas hoje, tantas, só hoje, tantas, têm os nomes que colam, colam ao céu da boca, colam 
caramelo a escorrer entre as pernas, e essa, a suprema felicidade de colar e não calar, sempre.

Colar é o colo das mulheres caldeiras, que aquecem, que são livros e aquecem como queimam. São palavras livros que queimam e aquecem. São palavras livros não escritos, nunca escritos que ficaram por escrever, mas que ocuparam o espaço da ideia e dos ais. Não escreveu, foi um ar que lhe deu.

Hoje, dia 8 de Março, dizem que é o dia dos direitos das mulheres, como o dia das barbatanas de tubarão, ou dos ninhos de andorinhas, do direito à sopa novidade, quando essa sopa é novidade e ser mulher agora, com voz e rosto, ainda é novidade. E falta tanto e faz falta.

Falta tanto ainda que colar, tanto para não calar. Faltam desenhos, falta encher as paredes de desenhos, de retratos, de todas as mulheres meninas, de todas as mulheres mulheres, de todas as mulheres que o escolhem ser. Faltam os retratos, coladinhos uns aos outros, a falar uns com os outros, umas com a outras, faltam os rostos a serem palavras para não calar. 0 rosto da mulher é o grito, nos lábios horizontais do rosto, nos lábios verticais do sexo. 0 rosto da mulher é um grito colado em cima de grito, em cima de grito, em cima de grito em cimadegritoemcimadegritoemcimadegritoemcimadegritoemcimadegritoemcimadegritoemci madegritoemcimadegrito.

Em.

No colar não há espaço entre as superfícies, só há amor e raiva e no que é rasgado, só resta agrafar.

Colar é o contrário de calar.

Adrienne

Djuna

Edna

Jane

Lisboa, 8 de Março de 2016 